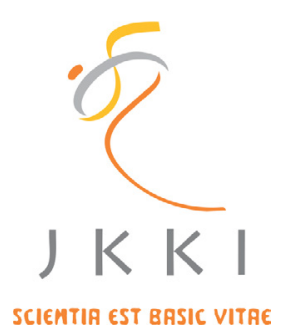

Jurnal Kedokteran dan Kesehatan Indonesia

Indonesian Journal of Medicine and Health

Journal homepage : www.journal.uii.ac.id/index.php/JKKI

\title{
Handsewn perineal rectosigmoidectomy (Altemeier) for complete full-thickness rectal prolapse: a case study
}

\author{
Adeodatus Yuda Handaya*1, Aditya Rifqi Fauzi ${ }^{1}$ \\ ${ }^{1}$ Digestive Surgery Division, Department of Surgery, Faculty of Medicine, Universitas Gadjah Mada/Dr. Sardjito \\ Hospital, Yogyakarta, Indonesia
}

Case Report

\begin{tabular}{|c|c|}
\hline & ABSTRACT \\
\hline ARTICLE INFO & \multirow{7}{*}{$\begin{array}{l}\text { Rectal prolapse is a condition in which the entire rectal wall layers } \\
\text { protrude through the anal canal. This condition rarely occurs, and the } \\
\text { management is still a challenge for both clinician and patient. Rectal } \\
\text { prolapse management can be done transabdominally or transperineally. } \\
\text { Full-thickness rectal prolapse in principle should have more attention to } \\
\text { the rectum function and anal sphincter to prevent recurrence and erectile } \\
\text { dysfunction. The Altemeier transperineal recto-sigmoid resection has } \\
\text { become the most common for surgical management of rectal prolapse. }\end{array}$} \\
\hline \multirow{5}{*}{$\begin{array}{l}\text { Keywords: } \\
\text { Rectal prolapse, } \\
\text { Perineal Rectosigmoidectomy, } \\
\text { Recurrence, } \\
\text { Incontinence, } \\
\text { Case study }\end{array}$} & \\
\hline & \\
\hline & \\
\hline & \\
\hline & \\
\hline $\begin{array}{l}\text { *Corresponding author: } \\
\text { yudahandaya@ugm.ac.id } \\
\end{array}$ & \\
\hline \multirow{4}{*}{$\begin{array}{l}\text { DOI : } 10.20885 / J K K I . V o l 9 . I s s 3 . a r t 10 \\
\text { History: } \\
\text { Received: July 31, } 2018 \\
\text { Accepted: October 1, } 2018 \\
\text { Online: December 31, } 2018 \\
\end{array}$} & We report four cases of rectal prolapse, two males and two females with \\
\hline & chief complaints had lumps out from their anus. All patients displayed \\
\hline & comorbidities. We performed the handsewn Altemeier procedure. \\
\hline & operative bleeding. Patients \\
\hline $\begin{array}{l}\text { Copyright @2018 Authors. } \\
\text {. }\end{array}$ & \\
\hline $\begin{array}{l}\text { his is an open access article } \\
\text { istributed under the terms }\end{array}$ & \\
\hline $\begin{array}{l}\text { f the Creative Commons At- } \\
\text { ibution-NonCommercial } 4.0\end{array}$ & \\
\hline $\begin{array}{l}\text { International Licence (http:// } \\
\text { creativecommons.org/licences/ } \\
\text { by-nc/4.0/). }\end{array}$ & $\begin{array}{l}\text { lity can be considered to be an alternative treatment } \\
\text { edure is relatively more accessible, safe, and has fewer }\end{array}$ \\
\hline
\end{tabular}

Prolaps rektum adalah suatu kondisi di mana seluruh lapisan dinding rektum menonjol melalui saluran anus. Kondisi ini jarang terjadi, dan manajemen masih merupakan tantangan bagi dokter dan pasien. Manajemen prolaps dubur dapat dilakukan secara transabdominal atau transperineal. Prolaps rektum dengan ketebalan penuh pada prinsipnya harus lebih memperhatikan fungsi rektum dan sfingter anal untuk mencegah kekambuhan dan disfungsi ereksi. Reseksi transperineal rekto-sigmoid Altemeier telah menjadi yang paling umum untuk manajemen bedah prolaps rektum. Kami melaporkan empat kasus prolaps rektum, dua pria dan dua wanita dengan keluhan utama memiliki benjolan keluar dari anus mereka. Semua pasien menunjukkan komorbiditas. Kami melakukan prosedur Altemeier. Semua operasi menghasilkan perdarahan intraoperatif minimal. Pasien tidak mengalami inkontinensia, fistula pasca operasi, perdarahan atau infeksi. Satu bulan setelah operasi, tidak ada pasien yang mengalami kekambuhan keluhan mereka. Menangani rektosigmoidektomi perineum untuk pengobatan prolaps rektal dengan ketebalan penuh pada pasien yang memiliki komorbiditas dapat dianggap sebagai pengobatan alternatif karena prosedur ini relatif lebih mudah diakses, aman, dan memiliki lebih sedikit komplikasi.

\section{INTRODUCTION}

Rectal prolapse is a condition in which all layers of the rectum wall protrude through the anal canal. ${ }^{1,2}$ Rectal prolapse is more common in women and happens more in the elderly population although it can affect both sexes 
and all ages, with an incidence of 4 per 1,000 inhabitants. In women, the peak incidence occurs at the end of the seventh decade, in men prolapse most commonly occurs at the age of 40 years or younger. ${ }^{3,4}$

The exact cause of rectal prolapse is not clear. Chronic constipation, female gender, multiparous pregnancy, previous pelvic surgery history, pelvic floor abnormalities, and neurologic abnormalities are predisposing factors for rectal prolapse., ${ }^{5,6}$ Five anatomical pathology elements that can be observed concerning this condition are 1) Loose levator ani muscles; 2) Deep cavum Douglas; 3) Ano-recto-colonic redundant pathologic anal; 4) Pathological fixation of the sacrum; and Loose rectum. ${ }^{2,3,6}$

The classification of rectal prolapse based on clinical examination is persistent prolapse, spontaneous prolapse and prolapse while straining. The main sign and symptoms of rectal prolapse are constipation and anal incontinence. ${ }^{1,2,6}$

Three types of rectal prolapse are known: complete rectal prolapse, mucosal rectal prolapse and internal rectal prolapse or invagination, also known as rectal intussusception into the anal canal without protrusion seen outside the anal. 2,6

In rectal prolapse patients, defecography, transrectal ultrasound and magnetic resonance imaging (MRI) can be done to visualise what cannot be seen in clinical examination. ${ }^{2,3}$

Rectal prolapse can be treated with surgical procedures. Surgery is divided into both open abdominal and laparoscopic approaches and perineal approach. ${ }^{1}$ The trans-perineal procedure is usually performed in older patients or with other conditions as comorbid. The most common perineal procedure for the severe form of rectal prolapse is perineal rectosigmoidectomy/ Altemeier procedure. The reported recurrence rate of only $2.8 \%{ }^{7}$

We conducted a case study with the subjects are patients from a tertiary hospital in Yogyakarta, Indonesia. The subjects are rectal prolapse patients who are having a comorbid condition. This case study is an operator experience as a digestive surgeon.

\section{Case reports \\ Case 1}

Sixty years old woman with chief complaint of having lumps out from vagina and anus, diagnosed as uterine prolapse and haemorrhoids. The patient was planning on the operation by obstetrics and digestive surgery. The digital rectal examination was done during operation after induction of anaesthesia, and the result was within reasonable limits, no lumps, with rectal prolapse $5 \mathrm{~cm}$ long. Hysterectomy procedure was done by Obstetrician, and perineal rectosigmoidectomy (Altemeier procedure) was conducted to manage the rectal prolapse. During the operation estimated bleeding was around $300 \mathrm{cc}$, with operation length 4 hours. The patient was hospitalised for four days. Postoperative checkups at seven days and one month later had found no bleeding, infection or anal incontinence.

\section{Case 2}

The 56-year-old female patient came with the chief complaint of the difficulty of defecation and always strained while doing so. The patient was treated and referred to an obstetrician because of uterine prolapse and was consulted to a surgeon with a complaint of obstipation. The patient's clinical appearance as in Figure 1 below (Fig.1). Colon was found in the loop during examination and colonoscopy was within normal limits. The digital rectal exam was also within reasonable limits. Rectal prolapse was seen with the length of $3 \mathrm{~cm}$. A joint operation with obstetrician performed trans-perineal hysterectomy and perineal rectosigmoidectomy (Altemeier procedure), with intra-operative bleeding, was estimated at $300 \mathrm{ccs}$, and the surgery duration was 4 hours. The patient was hospitalised for five days and went for checkups to the polyclinic at the seventh day, fourteenth day and one month after being discharged from the hospital, with no sign of bleeding, infection, nor lump in the anus. The patient had no difficulty in defecation, and no post-operative incontinence occurred. 


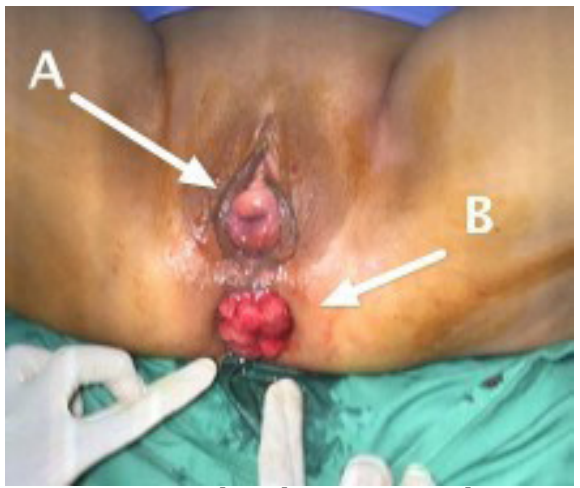

Figure 1. Rectal and Uterine Prolapse

\section{Case 3}

Eighteen years old male patient consulted from the Psychiatric department and hospitalised for mental retardation disorder. The family said there was a lump out from the anus. The patient was referred from primary health care with a diagnosis of haemorrhoids. On examination rectal prolapse with length, $7 \mathrm{~cm}$ was found. The altemeier procedure was done with 200 cc bleeding during operation, and duration of surgery was 2 hours. The patient was hospitalised for seven days and went for checkups to the polyclinic at the seventh day, fourteenth day and one month after being discharged from the hospital, with no sign of bleeding, infection, nor lump in the anus. The patient had no complaint about difficulty while straining.

\section{Case 4}

The 32-year-old male patient came with the chief complaint of a lump in the anus after having hemorrhoidectomy operation three times. The patient brought colonoscopy and colon in loop results, which were within reasonable limits. The trans-endoscopic biopsy result showed nonspecific inflammation. The patient is a young and sexually active male, who is undergoing invitro fertilisation program. In the intra-operative physical exam, we found the length of prolapse was $12 \mathrm{~cm}$ (Fig. 2). Perineal rectosigmoidectomy (Altemeier procedure) was performed with intraoperative bleeding $300 \mathrm{ccs}$, and the duration was 2.5 hours. After the operation was done, the patient got two transfusions of whole-blood. The patient had a fever then, and laboratory

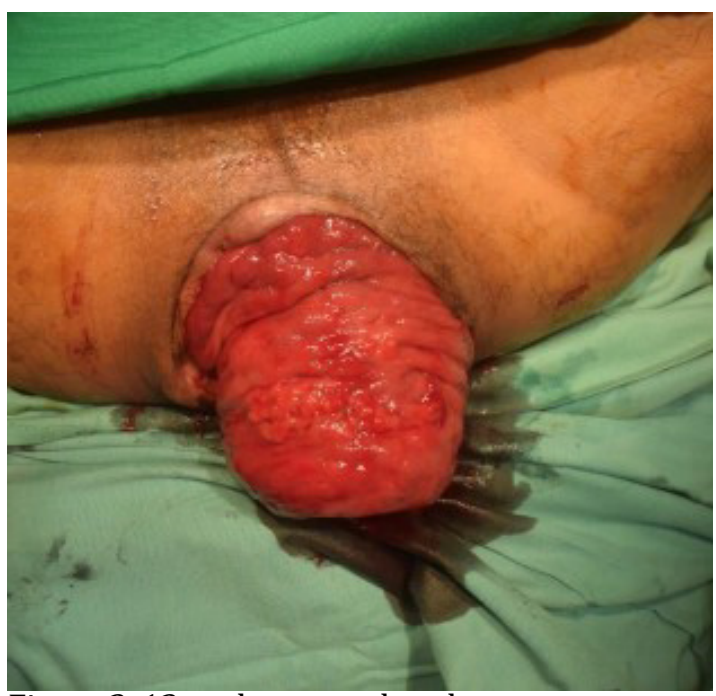

Figure $2.12 \mathrm{~cm}$ long rectal prolapse 


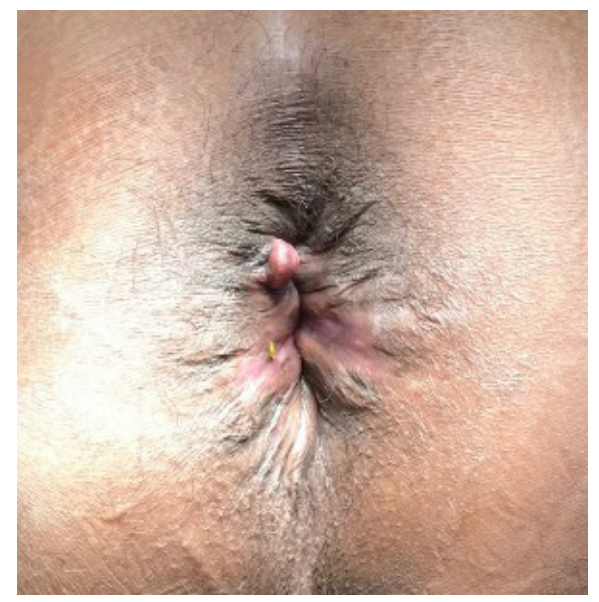

Figure 3. Postoperative follow-up after one month

examination result showed leukocytosis 19.000 $\mathrm{mg} / \mathrm{dl}$. Polyclinic checkups were on the seventh day, fourteenth day, and a month after being discharged, with no sign of bleeding, infection, nor lump in the anus. The patient complained still having difficulty holding back bowel movements within two weeks after the operation. At one month of evaluation, no incontinence occurred, and the patient can have daily activity as usual (Fig. 3).

Altemeier handsewn anastomosis operative technique:

- We performed Handsewn Perineal rectosigmoidectomy operative procedure with spinal anesthesia (Fig. 4)

- Then we evaluated and performed digital rectal examination after anesthesia; then we pulled the rectal prolapse toward the anus.

- We made an incision at 12 o'clock to all of the rectal prolapse layers from the tip of prolapse toward the cranial or anal canal.

- Continued with circular clockwise incision with the figure of 8 suture using absorbable multifilament 2.0 thread.

- The bleeding was controlled

- Then we gave spongostan anal tampon

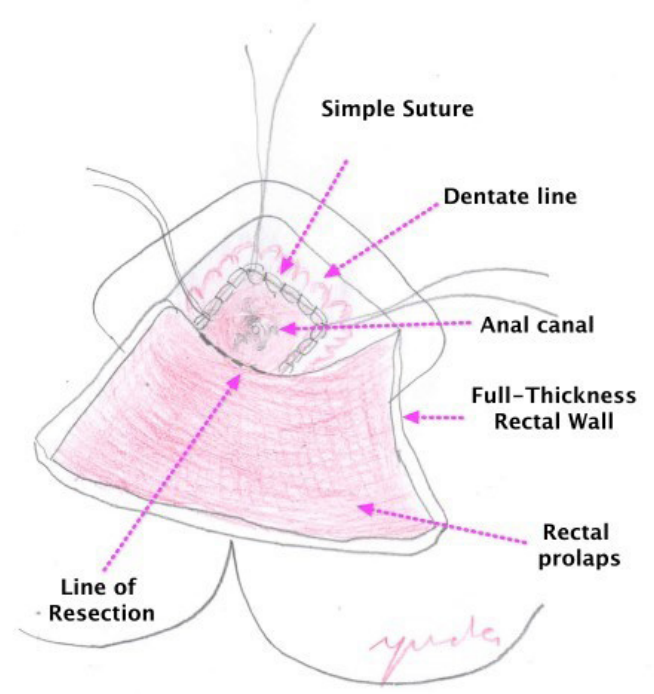

Figure 4. The Altemeier procedure 


\section{DISCUSSION}

Rectal prolapse is usually found in old adults, and the incidence is increased after 50 years of age. The mean age of our cases was $41.5 \pm 9.9$ years (range 18-60 years old)

Perineal rectosigmoidectomy (Altemeier) procedure is one method that currently becomes more popular in managing complete full-thickness rectal prolapse. This technique can be used on patients with long or short rectal prolapse. Perineal rectosigmoidectomy in patients with full-thickness rectal prolapse vary from $0 \%$ to $60 \%$.

The Altemeier procedure in principle aims to strengthen pelvic floor muscle after resecting the prolapses rectum, closing the Douglas pouch and performing levatorplasty. The complication of this procedure is $0-5 \%$, and the recurrence rate is $0-16 \%$. The incidence of leakage is very. It was also reported regarding faecal incontinence, the Altemeier procedure is better than the Delorme procedure. ${ }^{8}$ Handsewn technique is usually used as a modification from the perineal rectosigmoidectomy. Another modification from perineal rectosigmoidectomy is stapled anastomosis procedure. Our study is by a study by Kim et al. that report the operative technique including stapled anastomosis to be associated with a high recurrence. This means the handsewn procedure is superior to the stapled procedure. ${ }^{9}$ Handsewn suturing method was also widely used in another surgical procedure. Ramage et al. also used in the treatment of ultralow rectal cancer, the handsewn anastomosis reported being safe and feasible. ${ }^{10}$

Case 1 and case 3 patients had comorbid uterine prolapse, and the problem was corrected by an obstetrician with trans-perineal hysterectomy, so our procedure of choice was trans-perineal rectal prolapse repair. The second patient had mental retardation comorbidity, so our procedure of choice to correct the rectal prolapse was perineal rectosigmoidectomy because we considered the patient cannot take care of the post-operative wound from infection. The fourth patient chooses to have the perineal rectosigmoidectomy because the length of the prolapse was $12 \mathrm{~cm}$, and also the patient is sexually active and wanted to have children. The risk of the trans-abdominal approach was errigentes nerve injury in the pre-sacral area that can lead to sexual dysfunction.

Patients in the perineal approach group had a shorter length of stay (4-7 days) and shorter operation duration. The second patient with mental retardation and the fourth patient who had a very long rectal prolapse $(12 \mathrm{~cm})$ had a longer length of stay because we had to evaluate the bleeding and post-resection leakage. The perineal rectosigmoidectomy patients had a higher recurrence compared to the patients with the abdominal approach. In case 4 , after we evaluated the patient for six months, there were no recurrence and permanent incontinence, nor constipation. The patient was having incontinence only in the first week after the operation. The frequency of defecation after having abdominal surgery approach was estimated once daily (around 1-3 times). However, the perineal approach had a frequency of defecation for about three times a day (ranging 1-6 times). For our patients, they were having defecation 1-2 times a day, and our mentally disabled patient was defecating every one or two days. ${ }^{1,2}$

In our patients, the surgery took 2-4 hours long on average. In case 1 and 3, another obstetric-related procedure was performed by additional surgery in the form of trans-perineal hysterectomy. The perineal sigmoidectomy procedure had minus complications. This procedure is an option in elderly and young patients who have comorbid conditions (e.g., mental retardation). Intra-operative bleeding in $93 \%$ of patients is less than $200 \mathrm{cc}$, and the duration of surgery is 134.8 minutes on average. The average length of hospitalisation is 3.9 days. The mean recurrence rate is $0-18 \%$ in observations for four years. Mortality was reported to be $0-3.8 \%$ for the Altemeier procedure. ${ }^{11,12}$ In our patients, the bleeding was around 200-300 cc and increased in patients with large prolapse and with the additional procedure of transvaginal hysterectomy. Our 
cases have no mortality or morbidity.

The purpose of this report is to present our experience in managing complete rectal prolapse with comorbidity, with some technical modification to minimise the rate of complications. All of our patients have their complaints relieved in postoperative follow-up without incontinence symptom.

\section{CONCLUSION}

Surgery of complete full-thickness rectal prolapse by hand sewing is an option in rectal prolapse therapy in patients who are having comorbidity. The periodic follow-up of postoperative patients showed safe procedure with no symptoms of incontinence and recurrence. In the future, we need to do a more significant scale of research so that this technique can become a technical report.

\section{CONFLICT OF INTEREST}

No potential conflict of interest relevant to this article was reported.

\section{Acknowledgement}

We thank patient family, the surgical team and the nursing staff who were involved in the surgery and patients care.

\section{FUNDING}

The authors declare that they have no funding source.

\section{Ethical approval}

The informed consent form was declared that the patient data or samples would be used for educational or research purpose. Our institutional review board also do not provide an ethical approval in the form of a case study.

\section{Consent}

Written informed consent was obtained from the patient for publication of this case report and accompanying images. A copy of the written consent is available for review by the Editor-inchief of this journal on a reasonable request.

\section{Author contribution}

Adeodatus Yuda Handaya conceived the study. Aditya Rifqi Fauzi drafted the manuscript and critically revised the manuscript for important intellectual content. Adeodatus Yuda Handaya and Aditya Rifqi Fauzi facilitated all projectrelated tasks.

\section{REFERENCES}

1. Shin EJ.Surgical treatment of rectal prolapse. J Korean Soc Coloproctol. 2011;27(1):5-12.

2. Ortega AE, Cologne KG, Lee SW. Management of rectal prolapse -the state of the art. JSM Gen Surg Cases Images. 2017;2(1):1018.

3. Hayden DM, Wexner SD. Rectal prolapse: current evaluation, management, and treatment of a historically recurring disorder. Complexities in Colorectal Surgery. 2014;173.

4. Lee JL, Yang SS, Park IJ, Yu CS, Kim JC. Comparison of abdominal and perineal procedures for complete rectal prolapse: an analysis of 104 patients. Annals of Surgical Treatment and Research. 2014;86(5):24955.

5. Mostafa RM. Rectal prolapse: diagnosis and clinical management. World Journal of Gastroenterology. 2010;16(17):2193-4.

6. Murad-Regadas SM, Pinto RA. Treatment of rectal prolapse. Seminars in Colon and Rectal Surgery. 2016;27:33-9.

7. Bordeianou L, Pauette I, Johnson E, Holubar SD, Gaertner W, Feingold DL. Clinical practice guidelines for the treatment of rectal prolapse. Diseases of the Colon \& Rectum. 2017;60:1121-31.

8. Yoon SG. Rectal prolapse: review according to the personal experience. Journal of the Korean Society of Coloproctology. 2011;27(3):107-13.

9. Kim M, Reibetanz J, Schlegel N, Krajinovic K, Köstler H, Germer CT, et al. Recurrence after perineal rectosigmoidectomy: when and why? Colorectal Disease. 2014;16(11):9204.

10. Ramage L, Mclean P, Simillis C, Qiu S, Kontovounisios C, Tan E, et al. Functional outcomes with handsewn versus stapled anas- 
tomoses in the treatment of ultralow rectal cancer. Updates in surgery. 2018;70(1):1521.

11. Melton GB, Kwaan MR. Rectal Prolapse. Surgical Clinics of North America. 2013;93:187-98.

12. Holmes L, Bordeianou L. Perineal approaches to the treatment of rectal prolapse. Seminars in Colon and Rectal Surgery. 2011;22:50-5. 